SUPPORTING INFORMATION

\title{
Interfacial concentration of hydroxytyrosol and its lipophilic esters in intact olive oil-in water emulsions: effects of antioxidant hydrophobicity, surfactant concentration, and the oil-to-water ratio on the oxidative stability of the emulsions
}

\author{
João Almeida, Sonia Losada-Barreiro*, Marlene Costa, Fátima Paiva-Martins, \\ Carlos Bravo-Díaz, Laurence S. Romsted
}

S1. Determining AO distributions in intact emulsions: Application of the pseudophase kinetic model

The logic, basic assumptions, advantages, and limitations of the method including the discrete structures - separate continuous reaction regions duality concept that explains why reaction rates in emulsions as well as association colloids do not depend on droplet or aggregate size has been described in detail elsewhere. ${ }^{1}$ In brief, because reactant diffusivity is many orders of magnitude faster than the rate of the reaction between the $\mathrm{AO}$ and $16-\mathrm{ArN}_{2}{ }^{+}$in the interfacial region both reactants are in dynamic equilibrium throughout the time course of the reaction and molecular transport between the oil interfacial and aqueous regions does not affect the observed reaction rate. ${ }^{2-9}$

In binary oil-water systems, the distribution of reactants (e.g. antioxidants) is expressed by using a thermodynamic partition constant, $P_{\mathrm{w}}{ }^{0}$ defined by the ratio of concentrations of the antioxidant in the oil, $\mathrm{O}$, and water, $\mathrm{W}$, phases, equation 1 (see article), where parentheses ( ) indicate concentration in moles of AO per liter of phase volume. The concentrations in each region can be determined by means of any suitable analytical technique. ${ }^{10} P_{\mathrm{w}}{ }^{0}$ can also be defined as the ratio of the percentages of antioxidant, \%AO, and the volumes $V$ of the each region, equation 1 .

Addition of a surfactant to a binary oil-water system with stirring produces a kinetically stable emulsion (or if sufficient surfactant is added, a homogeneous microemulsion) that contains a new interfacial region between the oil and water regions. AO distribution must now be described by two partition constants. Scheme 1. $P_{\mathrm{W}}{ }^{\prime}$ between the aqueous and interfacial regions and $P_{0}^{\prime}$ between the oil and interfacial regions, defined by equations $s 2$ and $s 3$, respectively. Note that the value of the ratio $P_{\mathrm{w}}{ }^{\prime} / P_{\mathrm{O}}{ }^{\prime}$ is equal to that of the partition constant between the oil and water in the absence of surfactant, $P_{\mathrm{w}}{ }^{0}$, as shown in equation $\mathrm{s} 4$ (and equation 1 in article). This equation is used with the equations fitting kinetic data to solve for partition constants. To obtain independent estimates of both $P_{\mathrm{O}}^{\prime}$ and $P_{\mathrm{W}}^{\prime}$, a second 
independent equation, which also contains both terms is obtained from the fits of kinetic data in the emulsions, is combined and solved with equation s4 as two equations with two unknowns (see below).

As noted above, in pseudophase models both emulsions (and microemulsions) are divided into three reaction regions, the oil, interfacial and aqueous regions, Scheme 1 in the text. The volume fraction of each region is determined by the volumes of added oil, $V_{0}$, surfactant, $V_{1}$, and aqueous solution, $V_{\mathrm{w}}$, and is defined as the ratio between the volume of the region and the total volume, e.g., $\Phi_{1}=V_{1} /\left(V_{w}+V_{1}+V_{0}\right)$.

$$
\begin{aligned}
& P_{\mathrm{w}}^{\mathrm{O}}=\frac{\left(\mathrm{AO}_{\mathrm{O}}\right)}{\left(\mathrm{AO}_{\mathrm{w}}\right)}=\frac{\% \mathrm{AO}_{\mathrm{O}}}{\% \mathrm{AO}_{\mathrm{w}}} \frac{V_{\mathrm{w}}}{V_{\mathrm{O}}} \\
& P_{\mathrm{W}}{ }^{\mathrm{I}}=\frac{\left(\mathrm{AO}_{\mathrm{I}}\right)}{\left(\mathrm{AO}_{\mathrm{W}}\right)} \\
& P_{\mathrm{O}}^{\mathrm{I}}=\frac{\left(\mathrm{AO}_{\mathrm{I}}\right)}{\left(\mathrm{AO}_{\mathrm{O}}\right)} \\
& \frac{P_{\mathrm{W}}^{\mathrm{I}}}{P_{\mathrm{O}}^{\mathrm{I}}}=\frac{\left(\mathrm{AO}_{\mathrm{I}}\right) /\left(\mathrm{AO}_{\mathrm{W}}\right)}{\left(\mathrm{AO}_{\mathrm{I}}\right) /\left(\mathrm{AO}_{\mathrm{O}}\right)}=\frac{\left(\mathrm{AO}_{\mathrm{O}}\right)}{\left(\mathrm{AO}_{\mathrm{W}}\right)}=P_{\mathrm{W}}^{\mathrm{O}}
\end{aligned}
$$

After bulk mixing is complete, the distributions of reactants are determined by their relative solubilities in the oil, interfacial and aqueous regions. In organized media composed of simple surfactants, oil and water, the distributions of molecules and ions are in dynamic equilibrium and exchange rapidly between the three regions and the rate of the slow thermal reactions between the $A O$ and probe are not limited by diffusion of reactants. The emulsions were stirred continuously to maintain their kinetic stability, although they showed no visual separation in the absence of stirring for at least 6 hours (typical half-lives for the reaction between 16- $\mathrm{ArN}_{2}{ }^{+}$and $\mathrm{AOs}$ range 2-30 min). The cationic chemical probe, $16-\mathrm{ArN}_{2}{ }^{+}$, is oil insoluble because of its charge, but also water insoluble because of its hydrophobic alkyl chain and aromatic ring. Thus, $16-\mathrm{ArN}_{2}{ }^{+}$is located only in the interfacial region and oriented with its tail in the hydrophobic core and its headgroup in the interfacial region in contact with water, ${ }^{1,3}$ where it reacts with the AO (Scheme 1 in the text) Because both reactants and emulsion components are in dynamic equilibrium, and because the surfactant and $\mathrm{AO}$ concentrations are in large excess with respect to that of $16-\mathrm{ArN}_{2}{ }^{+}$, the chemical reaction does not signifigantly perturb the distribution of the reactants.

In summary, the main assumptions of the pseudophase kinetic model are: 
1) The distributions the reactants, $\mathrm{AO}$ and $16-\mathrm{ArN}_{2}{ }^{+}$, depends on their relative solubilities in the oil, interfacial and aqueous regions and not on droplet size or shape in the emulsion.

2) The reaction is run under pseudo first order conditions, $[\mathrm{AO}]>\left[16-\mathrm{ArN}_{2}{ }^{+}\right]$and, the reactants do not perturb the properties of the interfacial region in the emulsion droplets, [Tween 20] $>[\mathrm{AO}]$.

3) $\mathrm{AO}$ and $16-\mathrm{ArN}_{2}{ }^{+}$are in dynamic equilibrium within emulsions, i.e., their rates of transfer between regions are much faster than the thermal reaction between $16-\mathrm{ArN}_{2}{ }^{+}$and $\mathrm{AO}$.

Thus, overall rate of the bimolecular reaction, $\mathrm{v}$, in the interfacial region of an emulsion, Scheme 1, depends only on the measured (or observed) rate constant, $k_{\mathrm{obs}}$ and on the concentrations of $16-\mathrm{ArN}_{2}{ }^{+}$and antioxidant, $\mathrm{AO}$, in the interfacial region, equation s5. The third equality on the right hand side of equation s 5 illustrates the assumption that the rate of reaction depends on concentrations of reactants in the interfacial region in moles per liter of interfacial volume as indicated by ( ).

$\mathrm{V}=k_{\mathrm{obs}}\left[16-\mathrm{ArN}_{2 \mathrm{~T}}^{+}\right]=k_{2}\left[16-\mathrm{ArN}_{2 \mathrm{~T}}^{+}\right]\left[\mathrm{AO}_{\mathrm{T}}^{\mathrm{T}}\right]=k_{\mathrm{I}}\left(16-\mathrm{ArN}_{2 \mathrm{I}}^{+}\right)\left(\mathrm{AO}_{\mathrm{I}}^{\mathrm{T}}\right) \Phi_{\mathrm{I}}$

The reaction occurs only in the interfacial region because the concentration of $16-\mathrm{ArN}_{2}{ }^{+}$in oil and water is negligible. Thus, $\mathrm{v}$ depends four terms: $\left(\mathrm{AO}_{1}\right)$ and $\left(16-\mathrm{ArN}_{2}{ }_{1}\right)$ in moles per liter of interfacial volume; the second order interfacial rate constant, $k_{1} \mathrm{M}^{-1} \mathrm{~s}^{-1}$; and the volume fraction of the interfacial region, $\Phi_{1}$. Other terms include subscript $T$, which represents the stoichiometric or total concentration; $k_{\mathrm{obs}}$ and $k_{2}$ are the measured and overall second order rate constants, and square brackets, [ ], denote the concentration in molarity of total emulsion volume. Equations $s 4$ and $s 5$ are combined with the relevant mass balance equation to give the relationship between $k_{\mathrm{obs}}$ and partition constant values, equation $s 6,{ }^{1}$ where subscripts $\mathrm{W}, \mathrm{O}$, and I stand for water, oil and interfacial regions.

$k_{\text {obs }}=\frac{\left[\mathrm{AO}_{\mathrm{T}}\right] k_{\mathrm{I}} P_{\mathrm{W}}^{\mathrm{I}} P_{\mathrm{O}}^{\mathrm{I}}}{\Phi_{\mathrm{O}} P_{\mathrm{W}}^{\mathrm{I}}+\Phi_{\mathrm{I}} P_{\mathrm{W}}^{\mathrm{I}} P_{\mathrm{O}}^{\mathrm{I}}+\Phi_{\mathrm{W}} P_{\mathrm{O}}^{\mathrm{I}}}$

The mathematical treatment can be simplified for very hydrophilic and very hydrophobic AOs. For AOs that are oil insoluble, i.e., that distribute between the aqueous and interfacial region only the partition constant $P_{\mathrm{W}}{ }^{\prime}$ is needed to define its distribution and the derivation of equation $s 6$ simplifies to give equation s7. ${ }^{1,3}$ For water insoluble AOs, i.e., that distribute between the oil and interfacial regions, only the partition constant $P_{\mathrm{O}}{ }^{\prime}$ is needed and equation s6 simplifies to equation s8. 


$$
\begin{aligned}
& k_{\mathrm{obs}}=\frac{k_{\mathrm{I}}[\mathrm{AO}]_{\mathrm{T}} P_{\mathrm{W}}^{\mathrm{I}}}{\Phi_{\mathrm{I}} P_{\mathrm{W}}^{\mathrm{I}}+\Phi_{\mathrm{W}}} \\
& k_{\mathrm{obs}}=\frac{k_{\mathrm{I}}[\mathrm{AO}]_{\mathrm{T}} P_{\mathrm{O}}^{\mathrm{I}}}{\Phi_{\mathrm{I}} P_{\mathrm{O}}^{\mathrm{I}}+\Phi_{\mathrm{O}}}
\end{aligned}
$$

Equations s6-s8 predict that $k_{\text {obs }}$ values should decrease asymptotically with increasing $\Phi_{1}$. Equation $\mathrm{s} 9$ has the same form as the reciprocal of equation $\mathrm{s} 6$, where the parameters $a$ and $b$ are given by equations $s 10$ and $s 11$, respectively. Equations $s 12$ and $s 13$ are the reciprocals of equations $s 7$ and $s 8$, respectively, and they predict that plots of $1 / k_{\text {obs }} v s \Phi_{1}$ should be linear with positive intercepts. Equations s9, s12 and s13 were employed to calculate the partition constants $P_{\mathrm{O}}{ }^{\prime}$ and $P_{\mathrm{W}}{ }^{\prime}$ and the rate constant $k_{\mathrm{l}}$ in the interfacial region as described elsewhere. ${ }^{1,}$ 3

$$
\begin{aligned}
& \frac{1}{k_{o b s}}=\frac{1}{a}+\frac{b}{a} \Phi_{I} \\
& a=\frac{\left[\mathrm{AO}_{\mathrm{T}}\right] k_{\mathrm{I}} P_{\mathrm{W}}^{\mathrm{I}} P_{\mathrm{O}}^{\mathrm{I}}\left(1+\Phi_{\mathrm{W}} / \Phi_{\mathrm{O}}\right)}{P_{\mathrm{W}}^{\mathrm{I}}+\Phi_{\mathrm{W}} / \Phi_{\mathrm{O}} P_{\mathrm{O}}^{\mathrm{I}}} \\
& b=\frac{P_{W}^{I} P_{O}^{I}\left(1+\Phi_{W} / \Phi_{O}\right)}{P_{W}^{I}+\Phi_{W} / \Phi_{O} P_{O}^{I}}-1 \\
& \frac{1}{k_{o b s}}=\frac{\Phi_{\mathrm{W}}}{k_{\mathrm{I}}\left[\mathrm{AO} \mathrm{T}_{\mathrm{T}}\right] P_{\mathrm{W}}^{\mathrm{I}}}+\frac{1}{k_{\mathrm{I}}\left[\mathrm{AO} \mathrm{T}_{\mathrm{T}}\right]} \Phi_{\mathrm{I}} \\
& \frac{1}{k_{\mathrm{obs}}}=\frac{\Phi_{\mathrm{O}}}{k_{\mathrm{I}}[\mathrm{AO}]_{\mathrm{T}} \mathrm{P}_{\mathrm{O}}^{\mathrm{I}}}+\frac{1}{k_{\mathrm{I}}[\mathrm{AO}]_{\mathrm{T}}} \Phi_{\mathrm{I}}
\end{aligned}
$$

Once the partition constants are known, the distribution of the antioxidant can be determined as the percentage of the antioxidant in each region. Equations s14-s16 were employed to calculate the fraction of $\mathrm{AO}$ in the interfacial region for $\mathrm{AO}$ s that distributes between the three regions and for those that distribute between the aqueous-interfacial and oil-interfacial regions, respectively. Similar equations used to calculate the percentage of $A O$ in the oil and aqueous regions were derived previously and are published elsewhere. ${ }^{1,3}$

$$
\% \mathrm{AO}_{\mathrm{I}}=\frac{100 \Phi_{\mathrm{I}} P_{\mathrm{w}}^{\mathrm{I}} P_{\mathrm{O}}^{\mathrm{I}}}{\Phi_{\mathrm{O}} P_{\mathrm{W}}^{\mathrm{I}}+\Phi_{\mathrm{I}} P_{\mathrm{W}}^{\mathrm{I}} P_{\mathrm{O}}^{\mathrm{I}}+\Phi_{\mathrm{w}} P_{\mathrm{O}}^{\mathrm{I}}}
$$




$$
\begin{gathered}
\% \mathrm{AO}_{\mathrm{I}}=\frac{100 \Phi_{\mathrm{I}} P_{\mathrm{W}}^{\mathrm{I}}}{\Phi_{\mathrm{I}} P_{\mathrm{W}}^{\mathrm{I}}+\Phi_{\mathrm{W}}} \\
\% \mathrm{AO}_{\mathrm{I}}=\frac{100 \Phi_{\mathrm{I}} P_{\mathrm{O}}^{\mathrm{I}}}{\Phi_{\mathrm{I}} P_{\mathrm{O}}^{\mathrm{I}}+\Phi_{\mathrm{O}}}
\end{gathered}
$$

\section{S2. EXPERIMENTAL SECTION}

\section{S2.1. Materials}

Scheme S1 summarizes the enzymatic routes employed for the preparation of the HT esters according to published procedures at $\mathrm{T}=35{ }^{\circ} \mathrm{C}^{11,}{ }^{12}$ The $\mathrm{C}_{1}-\mathrm{C}_{6}$ derivatives were synthesized by direct esterification of $\mathrm{HT}$ with the corresponding fatty acid. The $\mathrm{C}_{8}-\mathrm{C}_{16}$ derivatives were prepared by transesterification with the corresponding fatty ester.

In a typical experiment, HT (3.24 mM) was added to a mixture of fatty acid or fatty ester $(9.72 \mathrm{mM})$ and $33 \mathrm{~mL}$ benzene containing $0.972 \mathrm{~g}$ of Novozym 435 in a dry round bottom flask and stirred for 2-4 days. The enzyme was removed by decanting off the solution, $80 \mathrm{~mL}$ of

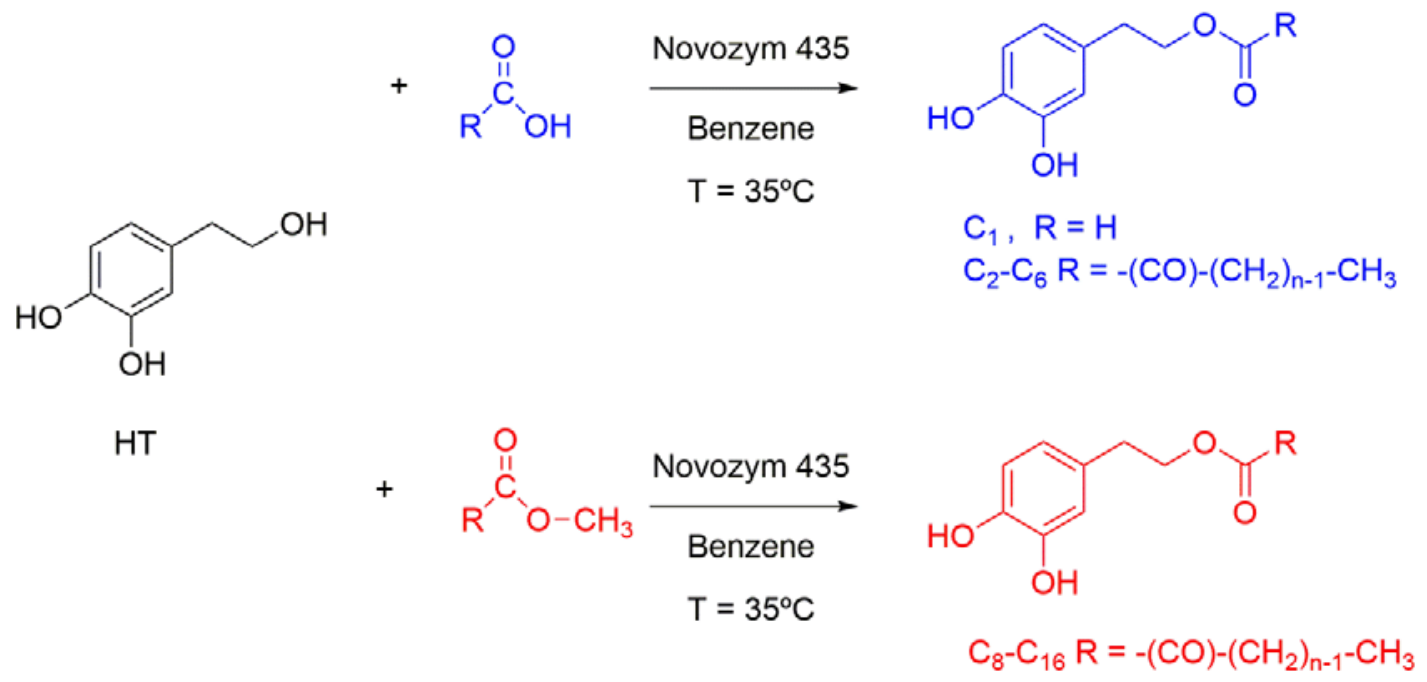

Scheme S1. Synthetic routes employed to prepare HT esters of different alkyl chain lengths.

diethyl ether was added, and the combined solution was extracted with aqueous $0.6 \mathrm{M} \mathrm{Na}_{2} \mathrm{CO}_{3}$ $(3 \times 30 \mathrm{~mL})$, and dried over $\mathrm{Na}_{2} \mathrm{SO}_{4}$. The solvent was evaporated and the product was purified by flash column chromatography over silica gel using ethyl acetate/petroleum ether as the eluent (1:1 (v:v) for the $C_{1}-C_{6}$ and 2:1 (v:v) for the $C_{8}-C_{16} H T$ derivatives). Final yields were > 
$60 \%$ for the $\mathrm{C}_{1}-\mathrm{C}_{6}$ and $\sim 50 \%$ for the $\mathrm{C}_{8}-\mathrm{C}_{16}$ derivatives. ${ }^{1} \mathrm{H}$ and ${ }^{13} \mathrm{C}$ NMR spectra for $\mathrm{HT}$ and its alkyl esters agree with literature results. ${ }^{11,12}$

\section{${ }^{1} \mathrm{H}$ NMR and ${ }^{13} \mathrm{C}$ NMR values for the $\mathrm{HT}$ derivatives}

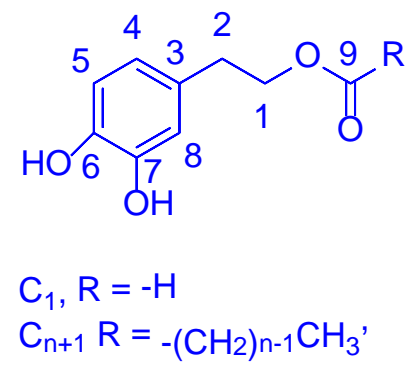

C. ${ }^{1} \mathrm{H}$ NMR (400 MHz, acetone D6): $\delta 7,7(1 \mathrm{H}, \mathrm{H}-9) ; 6,76(\mathrm{~d}, J=8,0 \mathrm{~Hz}, 1 \mathrm{H}, \mathrm{H}-5) ; 6,75(\mathrm{~d}, J=8$ $\mathrm{Hz}, 1 \mathrm{H}, \mathrm{H}-8) ; 6,59\left(\mathrm{dd},{ }^{3} J=8,0 \mathrm{~Hz},{ }^{4} J=2,0 \mathrm{~Hz}, 1 \mathrm{H}, \mathrm{H}-4\right) ; 4,27$ (t, $\left.J=8,0 \mathrm{~Hz}, 2 \mathrm{H}, \mathrm{H}-1\right) ; 2,81$ (t, $J=$ $8,0 \mathrm{~Hz}, 2 \mathrm{H}, \mathrm{H}-2) .{ }^{13} \mathrm{C}$ NMR (100 MHz, acetone D6): $\delta 161,9$ (C-9); 145,9 (C-7); 144,6 (C-6); 130,2 (C-3); 121,1 (C-4); 116,8 (C-5); 116,1 (C-8); 65,2 (C-1); 35,0 (C-2).

C. ${ }^{1} \mathrm{H}$ NMR (400 MHz, acetone D6): $\delta 6,75$ (d, $\left.J=8,0 \mathrm{~Hz}, 1 \mathrm{H}, \mathrm{H}-5\right) ; 6,74(\mathrm{~d}, J=8,0 \mathrm{~Hz}, 1 \mathrm{H}, \mathrm{H}-8$ ); $6,58\left(\mathrm{dd},{ }^{3} J=8,0 \mathrm{~Hz},{ }^{4} J=2,0 \mathrm{~Hz}, 1 \mathrm{H}, \mathrm{H}-4\right) ; 4,15(\mathrm{t}, J=8,0 \mathrm{~Hz}, 2 \mathrm{H}, \mathrm{H}-1) ; 2,76(\mathrm{t}, J=8,0 \mathrm{~Hz}, 2 \mathrm{H}, \mathrm{H}-$ 2); $1,96(\mathrm{t}, J=8,0 \mathrm{~Hz}, 3 \mathrm{H}, \mathrm{H}-10) .{ }^{13} \mathrm{C}$ NMR (100 MHz, acetone D6): $\delta$ 170,0 (C-9); 145,0 (C-7); 143,6 (C-6); 129,7 (C-3); 120,1 (C-4); 115,9 (C-5); 115,2 (C-8); 64,8 (C-1); 34,2 (C-2); 27,0 (C-10).

C. ${ }^{1} \mathrm{H}$ NMR (400 MHz, acetone D6): $\delta 6,76$ (d, $\left.J=8,0 \mathrm{~Hz}, 1 \mathrm{H}, \mathrm{H}-5\right) ; 6,75(\mathrm{~d}, J=8,0 \mathrm{~Hz}, 1 \mathrm{H}, \mathrm{H}-8$ ); $6,58\left(\mathrm{dd},{ }^{3} J=8,0 \mathrm{~Hz},{ }^{4} J=2,0 \mathrm{~Hz}, 1 \mathrm{H}, \mathrm{H}-4\right) ; 4,18(\mathrm{t}, J=8,0 \mathrm{~Hz}, 2 \mathrm{H}, \mathrm{H}-1) ; 2,77(\mathrm{t}, J=8,0 \mathrm{~Hz}, 2 \mathrm{H}, \mathrm{H}-$ 2); 2,28 (quart, $J=8,0 \mathrm{~Hz}, 2 \mathrm{H}, \mathrm{H}-10) ; 1,05(\mathrm{t}, J=8,0 \mathrm{~Hz}, 3 \mathrm{H}, \mathrm{H}-11) .{ }^{13} \mathrm{C}$ NMR (100 MHz, acetone D6): $\delta 173,5$ (C-9); 145,0 (C-7); 143,6 (C-6); 129,7 (C-3); 120,2 (C-4); 116,0 (C-5); 115,2 (C-8); 64,8 (C-1); 34,3 (C-2); 27,0 (C-10); 8,5 (C-11).

C. ${ }^{1} \mathrm{H}$ NMR (400 MHz, acetone D6): $\delta 6,76(\mathrm{~d}, J=8,0 \mathrm{~Hz}, 1 \mathrm{H}, \mathrm{H}-5) ; 6,75(\mathrm{~d}, J=8,0 \mathrm{~Hz}, 1 \mathrm{H}, \mathrm{H}-8$ ); $6,58\left(\mathrm{dd},{ }^{3} J=8,0 \mathrm{~Hz},{ }^{4} J=2.0 \mathrm{~Hz}, 1 \mathrm{H}, \mathrm{H}-4\right) ; 4,18(\mathrm{t}, J=8,0 \mathrm{~Hz}, 2 \mathrm{H}, \mathrm{H}-1) ; 2 ; 76(\mathrm{t}, J=8,0 \mathrm{~Hz}, 2 \mathrm{H}, \mathrm{H}-$ 2); 2,24 (t, $J=8,0 \mathrm{~Hz}, 2 \mathrm{H}, \mathrm{H}-10) ; 1,58$ (sext, $J=8,0 \mathrm{~Hz}, 2 \mathrm{H}, \mathrm{H}-11$ ); 0,89 (t, $J=8,0 \mathrm{~Hz}, 3 \mathrm{H}, \mathrm{H}-12$ ). ${ }^{13}$ C NMR (100 MHz, acetone D6): $\delta$ 173,5 (C-9); 145,9 (C-7); 144,5 (C-6); 130,6 (C-3); 121,0 (C4); 116,8 (C-5); 116,0 (C-8); 65,6 (C-1); 36,5 (C-2); 35,2 (C-10); 19,0 (C-11); 13,8 (C-12).

C $6 .{ }^{1} \mathrm{H}$ NMR (400 MHz, acetone D6): $\delta 6,75$ (d, $\left.J=8,0 \mathrm{~Hz}, 1 \mathrm{H}, \mathrm{H}-5\right) ; 6,74(\mathrm{~d}, J=8,0 \mathrm{~Hz}, 1 \mathrm{H}, \mathrm{H}-8$ ); $6,58\left(\mathrm{dd},{ }^{3} J=8,0 \mathrm{~Hz},{ }^{4} J=2,0 \mathrm{~Hz}, 1 \mathrm{H}, \mathrm{H}-4\right) ; 4,18(\mathrm{t}, J=8,0 \mathrm{~Hz}, 2 \mathrm{H}, \mathrm{H}-1) ; 2,77(\mathrm{t}, J=8,0 \mathrm{~Hz}, 2 \mathrm{H}, \mathrm{H}-$ 
2); 2,26 (t, $J=8,0 \mathrm{~Hz}, 2 \mathrm{H}, \mathrm{H}-10) ; 1,57$ (quint, $J=8,0 \mathrm{~Hz}, 2 \mathrm{H}, \mathrm{H}-11) ; 1,28(\mathrm{~m}, 4 \mathrm{H}, \mathrm{H}-12) ; 0,88$ (t, $J=$ $8,0 \mathrm{~Hz}, 3 \mathrm{H}, \mathrm{H}-13) .{ }^{13} \mathrm{C}$ NMR (100 MHz, acetone D6): $\delta$ 172,8 (C-9); 145,0 (C-7); 143,6 (C-6); 129,7 (C-3); 120,1 (C-4); 115,9 (C-5); 115,2 (C-8); 64,7 (C-1); 34,3 (C-2); 33,7 (C-10); 31,1 (C-11); 24,5 (C12); 22,1 (C-13); 13,3 (C-14).

C. ${ }^{1} \mathrm{H}$ NMR (400 MHz, acetone D6): $\delta 6,75$ (d, $\left.J=8,0 \mathrm{~Hz}, 1 \mathrm{H}, \mathrm{H}-5\right) ; 6,74(\mathrm{~d}, J=8,0 \mathrm{~Hz}, 1 \mathrm{H}, \mathrm{H}-8$ ); $6,58\left(\mathrm{dd},{ }^{3} J=8,0 \mathrm{~Hz},{ }^{4} J=2,0 \mathrm{~Hz}, 1 \mathrm{H}, \mathrm{H}-4\right) ; 4,17(\mathrm{t}, J=8,0 \mathrm{~Hz}, 2 \mathrm{H}, \mathrm{H}-1) ; 2,77(\mathrm{t}, J=8,0 \mathrm{~Hz}, 2 \mathrm{H}, \mathrm{H}-$ 2); $2,26(\mathrm{t}, J=8,0 \mathrm{~Hz}, 2 \mathrm{H}, \mathrm{H}-10) ; 1,57$ (quint, $J=8,0 \mathrm{~Hz}, 2 \mathrm{H}, \mathrm{H}-11) ; 1,28(\mathrm{~m}, 6 \mathrm{H}, \mathrm{H}-12) ; 0,88(\mathrm{t}, J=$ $8,0 \mathrm{~Hz}, 3 \mathrm{H}, \mathrm{H}-13) .{ }^{13} \mathrm{C}$ NMR (100 MHz, acetone D6): $\delta$ 172,7 (C-9); 145,0 (C-7); 143,9 (C-6); 129,7 (C-3); 120,1 (C-4); 115,8 (C-5); 115,2 (C-8); 64,7 (C-1); 34,3 (C-2); 33,8 (C-10); 31,5 (C-11); 24,8 (C12); 24,8 (C13); 22,4 (C-14); 22,4 (C-15); 13,4 (C-16).

$\mathrm{C}_{10} .{ }^{1} \mathrm{H}$ NMR (400 MHz, acetone D6): $\delta 6,75(\mathrm{~d}, J=8,0 \mathrm{~Hz}, 1 \mathrm{H}, \mathrm{H}-5) ; 6,74(\mathrm{~d}, J=8,0 \mathrm{~Hz}, 1 \mathrm{H}, \mathrm{H}-8$ ); $6,58\left(\mathrm{dd},{ }^{3} J=8,0 \mathrm{~Hz},{ }^{4} J=2,0 \mathrm{~Hz}, 1 \mathrm{H}, \mathrm{H}-4\right) ; 4,18(\mathrm{t}, J=8,0 \mathrm{~Hz}, 2 \mathrm{H}, \mathrm{H}-1) ; 2,77(\mathrm{t}, J=8,0 \mathrm{~Hz}, 2 \mathrm{H}, \mathrm{H}-$ 2); $2,28(\mathrm{t}, J=8,0 \mathrm{~Hz}, 2 \mathrm{H}, \mathrm{H}-10) ; 1,57$ (quint, $J=8,0 \mathrm{~Hz}, 2 \mathrm{H}, \mathrm{H}-11) ; 1,29(\mathrm{~m}, 12 \mathrm{H}, \mathrm{H}-12) ; 0,88(\mathrm{t}, J$ $=8,0 \mathrm{~Hz}, 3 \mathrm{H}, \mathrm{H}-13) .{ }^{13} \mathrm{C}$ NMR (100 MHz, acetone D6): $\delta$ 172,7 (C-9); 145,0 (C-7); 143,6 (C-6); 129,7 (C-3); 120,3 (C-4); 115,9 (C-5); 115,1 (C-8); 64,6 (C-1); 34,3 (C-2); 33,8 (C-10); 31,7 (C-11); 24,8 (C12); 24,8 (C13); 24,8 (C14); 22,4 (C-15); 22,4 (C-16); 22,4 (C-17); 13,5 (C-18).

$\mathrm{C}_{12} .{ }^{1} \mathrm{H}$ NMR (400 MHz, acetone D6): $\delta 6,75$ (d, $\left.J=8,0 \mathrm{~Hz}, 1 \mathrm{H}, \mathrm{H}-5\right) ; 6,74$ (d, $J=8,0 \mathrm{~Hz}, 1 \mathrm{H}, \mathrm{H}-8$ ); $6,58\left(\mathrm{dd},{ }^{3} J=8,0 \mathrm{~Hz},{ }^{4} J=2,0 \mathrm{~Hz}, 1 \mathrm{H}, \mathrm{H}-4\right) ; 4,17(\mathrm{t}, J=8,0 \mathrm{~Hz}, 2 \mathrm{H}, \mathrm{H}-1) ; 2,77(\mathrm{t}, J=8,0 \mathrm{~Hz}, 2 \mathrm{H}, \mathrm{H}-$ 2), 2,26 (t, $J=8,0 \mathrm{~Hz}, 2 \mathrm{H}, \mathrm{H}-10) ; 1,57$ (quint, $J=8,0 \mathrm{~Hz}, 2 \mathrm{H}, \mathrm{H}-11$ ), 1,29 (m, 16H, H-12); 0,88 (t, $J$ $=8,0 \mathrm{~Hz}, 3 \mathrm{H}, \mathrm{H}-13) .{ }^{13} \mathrm{C}$ NMR (100 MHz, acetone D6): $\delta$ 172,7 (C-9); 145,0 (C-7); 143,6 (C-6); 129,7 (C-3); 120,1 (C-4); 115,8 (C-5); 115,2 (C-8); 64,7 (C-1); 34,3 (C-2); 33,8 (C-10); 31,7 (C-11); 24,8 (C12); 24,8 (C13); 24,8 (C14); 24,8 (C15); 22,4 (C-16); 22,4 (C-17); 22,4 (C-18); 22,4 (C-19); $13,5(C-20)$.

$\mathrm{C}_{\text {14. }}{ }^{1} \mathrm{H}$ NMR (400 MHz, acetone D6): $\delta 6,75(\mathrm{~d}, J=8,0 \mathrm{~Hz}, 1 \mathrm{H}, \mathrm{H}-5) ; 6,74(\mathrm{~d}, J=8,0 \mathrm{~Hz}, 1 \mathrm{H}, \mathrm{H}-8$ ); $6,57\left(\mathrm{dd},{ }^{3} J=8,0 \mathrm{~Hz},{ }^{4} J=2,0 \mathrm{~Hz}, 1 \mathrm{H}, \mathrm{H}-4\right) ; 4,17(\mathrm{t}, J=8,0 \mathrm{~Hz}, 2 \mathrm{H}, \mathrm{H}-1), 2,76(\mathrm{t}, J=8,0 \mathrm{~Hz}, 2 \mathrm{H}, \mathrm{H}-$ 2); $2,26(\mathrm{t}, J=8,0 \mathrm{~Hz}, 2 \mathrm{H}, \mathrm{H}-10) ; 1,56$ (quint, $J=8,0 \mathrm{~Hz}, 2 \mathrm{H}, \mathrm{H}-11) ; 1,29(\mathrm{~m}, 16 \mathrm{H}, \mathrm{H}-12) ; 0,88$ (t, $J$ $=8,0 \mathrm{~Hz}, 3 \mathrm{H}, \mathrm{H}-13) .{ }^{13} \mathrm{C}$ NMR (100 MHz, acetone D6): $\delta$ 173,6 (C-9); 145,8 (C-7); 144,5 (C-6); 130,6 (C-3); 121,0 (C-4); 116,8 (C-5); 116,0 (C-8); 65,6 (C-1); 35,2 (C-2); 34,7 (C-10); 32,6 (C-11); 25,7 (C12); 25,7 (C13); 25,7 (C14); 25,7 (C15); 25,7 (C16); 23,3 (C-17); 23,3 (C-18); 23,3 (C-19); 23,3 (C-20); 23,3 (C-21); 14,5 (C-22). 
$\mathrm{C}_{16 .}{ }^{1} \mathrm{H}$ NMR (400 MHz, acetone D6): $\delta 6,75(\mathrm{~d}, J=8,0 \mathrm{~Hz}, 1 \mathrm{H}, \mathrm{H}-5) ; 6,74(\mathrm{~d}, J=8,0 \mathrm{~Hz}, 1 \mathrm{H}, \mathrm{H}-8$ ); $6,58\left(\mathrm{dd},{ }^{3} J=8,0 \mathrm{~Hz},{ }^{4} J=2,0 \mathrm{~Hz}, 1 \mathrm{H}, \mathrm{H}-4\right) ; 4,17(\mathrm{t}, J=8,0 \mathrm{~Hz}, 2 \mathrm{H}, \mathrm{H}-1) ; 2,76(\mathrm{t}, J=8.0 \mathrm{~Hz}, 2 \mathrm{H}, \mathrm{H}-$ 2); $2,26(\mathrm{t}, J=8,0 \mathrm{~Hz}, 2 \mathrm{H}, \mathrm{H}-10) ; 1,57$ (quint, $J=8,0 \mathrm{~Hz}, 2 \mathrm{H}, \mathrm{H}-11) ; 1,29(\mathrm{~m}, 24 \mathrm{H}, \mathrm{H}-12) ; 0,88$ (t, $J$ $=8,0 \mathrm{~Hz}, 3 \mathrm{H}, \mathrm{H}-13) .{ }^{13} \mathrm{C}$ NMR (100 MHz, acetone D6): $\delta$ 173,6 (C-9); 145,9 (C-7); 144,5 (C-6); 130,6 (C-3); 122,0 (C-4); 116,8 (C-5); 116,0 (C-8); 65,6 (C-1); 35,2 (C-2); 34,7 (C-10); 32,7 (C-11); 25,7 (C12); 25,7 (C13); 25,7 (C14); 25,7 (C15); 25,7 (C16); 25,7 (C17); 23,3 (C-18); 23,3 (C-19); 23,3 (C-20); 23,3 (C-21); 23,3 (C-22); 23,3 (C-23); 14,4 (C-24).

\section{S.2.2 Methods.}

\section{S.2.2.1. Preparation of Emulsions}

Emulsions of different oil to water ratios ( $4: 6$ and 1:9 v:v. $V_{T}=10 \mathrm{~mL}$ ) were prepared from stripped olive oil, acidic water ( $0.04 \mathrm{M}$ citrate buffer, $\mathrm{pH} 3.65$ ) and Tween 20 as emulsifier ( 0.5 - $4 \% \mathrm{w} / \mathrm{w})$. Before homogenization, hydrophilic AOs $\left(C_{1}-C_{3}\right)$ were added to the aqueous buffer and hydrophobic AOs $\left(\geq C_{4}\right)$ were added to the oil phase. The mixtures were stirred at high speed at room temperature with the aid of a Polytronic PT-1600 homogenizer for $1 \mathrm{~min}$ and the resulting emulsions were visually stable for at least 12 hours, a much longer time than that required to complete the chemical reaction between $16-\mathrm{ArN}_{2}{ }^{+}$and the AOs, which is typically < $30 \mathrm{~min}$ for 3-4 half-lives of reaction (see below).

S.2.2.2. $D P P H^{\bullet}$ radical scavenging activity. Determination of $E C_{50}$ values for $H T$ Esters: $A$ test for radical activity dependence $A O$ chain length.

Our procedure for determining $\mathrm{EC}_{50}$ values as a function of $\mathrm{AO}$ chain length has been published in detail. ${ }^{4,13}$ The rate of disappearance of $\mathrm{DPPH}^{\bullet}$ from reaction with each $\mathrm{AO}$ was monitored at $515 \mathrm{~nm}$ by using a Powerwave XS Microplate Reader (Bio-Tek Instruments, Inc) thermostated at $\mathrm{T}=25.0 \pm 0.1{ }^{\circ} \mathrm{C}$. The wells of a 96-well microplate contained a methanolic solution of $\mathrm{AO}(3-20 \mu \mathrm{M})$ and $80 \mu \mathrm{M} \mathrm{DPPH}$. The absorbance of each well was recorded at one min intervals for a 60 min period. The absorbance of each solution was subtracted from the blank (80 $\mu \mathrm{M} \mathrm{DPPH}^{\bullet}$ solution without $\left.\mathrm{AO}\right)$.

The value of $\mathrm{EC}_{50}$ for each $\mathrm{AO}$ was obtained in a two-step process. First, the $\mathrm{DPPH}^{\bullet}$ absorbance as a function of time (up to 60 minutes) was plotted for six mole AO/mole $\mathrm{DPPH}^{\bullet}$ ratios between 3-20 $\mu \mathrm{L}$ of $A O$. The percentage of the remaining $\mathrm{DPPH}^{\bullet}$ at a certain time of reaction was determined as $\% \mathrm{DPPH}^{\bullet}=100\left[\mathrm{DPPH}^{\bullet}(\right.$ time $=\mathrm{t}) / \mathrm{DPPH}^{\bullet}\left(\right.$ time $\left.\left.=\mathrm{t}_{\mathrm{o}}\right)\right]$. Second, the 
$\% \mathrm{DPPH}^{\bullet}$ was plotted against the mole $\mathrm{AO} / \mathrm{mol}^{\mathrm{DPPH}}{ }^{\bullet}$ ratio at selected times of reaction $(5,15$, 30 and $60 \mathrm{~min}$ ). On these plots, the value of $\mathrm{EC}_{50}$ is equal to the value the intersection of the line at $\% \mathrm{DPPH}^{\bullet}=50 \%$. Representative plots are shown below. Each sets of experiments was performed in quadruplicate. The $\mathrm{EC}_{50}$ values given in Table $\mathbf{S 1}$ are the average of these repetitions. Note that the variations in $\mathrm{EC}_{50}$ times are small and virtually independent of $\mathrm{AO}$ chain length.

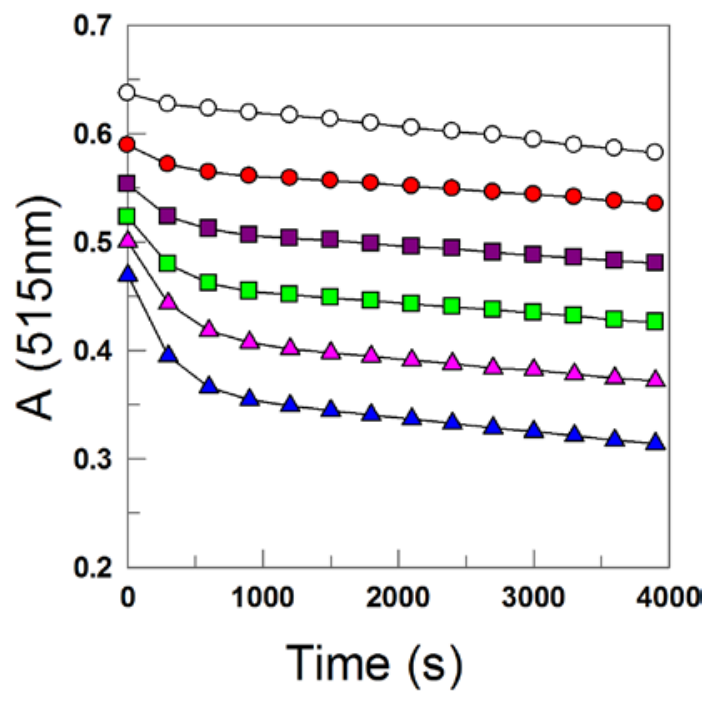

Figure S1. The time course for the change in $\mathrm{DPPH}^{\bullet}$ absorbance, (initial $\mathrm{DPPH}^{\bullet}$ ] $=100 \mu \mathrm{M}$ ) with six different concentrations of $A O=C_{3}$ expressed as mole ratios of $C_{3}$ to $\mathrm{DPPH}^{\bullet}$. $\left[C_{3}\right]=0.047-$ $0.282 \mathrm{M}\left(\left[\mathrm{C}_{3}\right] \sim 5 \%\right.$ to $25 \%$ of [mole AO/mole $\mathrm{DPPH}^{\bullet}:-\mathrm{O}-0.0470,-\mathrm{O}-0.0940$, $0.1410, \square-0.1880, \triangle 0.2350$, and $\triangle 0.2820$.

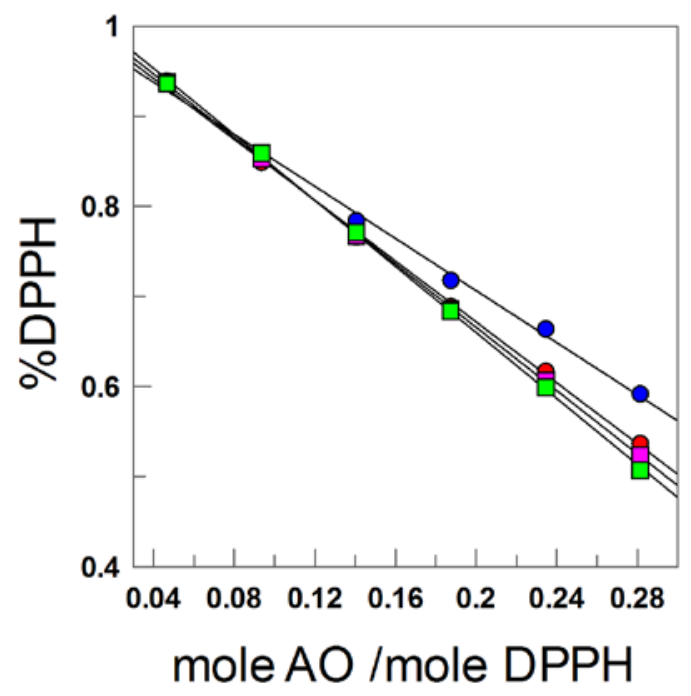


Figure S2. Percentage of initial DPPH radical remaining after $5(\bullet), 15(\bullet), 30(\square)$ and $60(\square)$ minutes of reaction with six different concentrations of $C_{3}$, plotted against the mole ratio of $A O$ to $\mathrm{DPPH}^{\bullet}$ at constant time. The $\mathrm{EC}_{50}$ values obtained at each time interval are also listed here and in Table S1.

\section{S2.2.3. Oxidative stability of emulsions: antioxidant efficiency}

The oxidative stability of food lipids is usually estimated by determining the extent of oxidation under a set of standardized conditions. ${ }^{14}$ In previous work, we estimated the efficiency of the AOs by measuring the degree of oxidation from the production of conjugated dienes $(C D)$ with time and we used this method here to compare with previous results with other AOs and because it is a sensitive and reproducible (and identical with the AOCS official standard method $\left.{ }^{15} \mathrm{Ti}-1 \mathrm{a}-64\right)$ for following the early stages of lipid oxidation. In addition, we have shown in previous work ${ }^{4,5}$ that monitoring primary and secondary products under similar conditions to those used here lead to the same conclusions. No visual phase separation was observed in the emulsions and the small increase constant up to sudden increase in the formation of conjugated dienes, Figure 1 in Results, suggests that phase separation, if any, does not have a significant effect on the kinetics of the reaction.

Table S1. $\mathrm{EC}_{50}$ (mole AO / mole $\mathrm{DPPH}^{\bullet}$ ) values for $\mathrm{HT}$ derivatives obtained at different reaction rimes with a level of significance $P<0.05$.

\begin{tabular}{|c|c|c|c|c|}
\hline AO & \multicolumn{5}{|c|}{15} & 30 & 60 \\
\hline$t$ (min) & 5 & $0.2867 \pm 0.0040$ & $0.2787 \pm 0.0039$ & $0.2582 \pm 0.0044$ \\
\hline$H T$ & $0.3230 \pm 0.0053$ & & & \\
\hline$C_{1}$ & $0.3378 \pm 00047$ & $0.2956 \pm 0.0031$ & $0.2882 \pm 0.0026$ & $0.2766 \pm 0.0030$ \\
\hline$C_{2}$ & $0.3542 \pm 0.0086$ & $0.3093 \pm 0.0075$ & $0.2980 \pm 0.0071$ & $0.2811 \pm 0.0057$ \\
\hline$C_{3}$ & $0.3445 \pm 0.0043$ & $0.2989 \pm 0.0024$ & $0.2895 \pm 0.0051$ & $0.2802 \pm 0.0033$ \\
\hline$C_{4}$ & $0.3478 \pm 0.0048$ & $0.2827 \pm 0.0018$ & $0.2723 \pm 0.0041$ & $0.2586 \pm 0.0017$ \\
\hline$C_{6}$ & $0.3002 \pm 0.0028$ & $0.2722 \pm 0.0093$ & $0.2630 \pm 0.0054$ & $0.2474 \pm 0.0025$ \\
\hline$C_{8}$ & $0.2949 \pm 0.0053$ & $0.2648 \pm 0.0048$ & $0.2558 \pm 0.0074$ & $0.2386 \pm 0.0034$ \\
\hline
\end{tabular}




\begin{tabular}{|l|l|l|l|l|}
$\mathrm{C}_{10}$ & $0.3262 \pm 0.0051$ & $0.2919 \pm 0.0045$ & $0.2859 \pm 0.0069$ & $0.2799 \pm 0.0041$ \\
\hline $\mathrm{C}_{12}$ & $0.3448 \pm 0.0048$ & $0.3189 \pm 0.0038$ & $0.3091 \pm 0.0108$ & $0.2937 \pm 0.0063$ \\
\hline $\mathrm{C}_{14}$ & $0.3474 \pm 0.0022$ & $0.3107 \pm 0.0023$ & $0.3005 \pm 0.0037$ & $0.2838 \pm 0.0028$ \\
\hline $\mathrm{C}_{16}$ & $0.3311 \pm 0.0112$ & $0.3052 \pm 0.0060$ & $0.3016 \pm 0.0121$ & $0.2980 \pm 0.0070$ \\
\hline
\end{tabular}

Oil-in-water emulsions (4:6 v:v $10 \mathrm{~mL}$ ) were prepared as above in the presence and absence of AOs (final AO concentration of $0.6 \mathrm{mM}$ ) and transferred to screw-capped sample

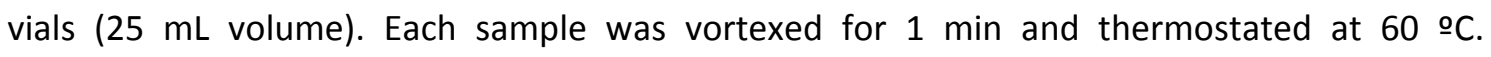
Thereafter, each sample was vortexed for one minute every 12 hours to minimize any potential effects caused by phase separation. After each vortex mixing, a $50 \mu$ laliquot of an emulsion was diluted to $10 \mathrm{ml}$ with ethanol, producing a homogeneous solution, and the absorbance at $233 \mathrm{~nm}$ was measured.

S.2.2.4. Determining the partition constant of $P_{\mathrm{w}}{ }^{0}$ in binary oil-water mixtures in the absence of emulsifier.

The partition constants, $P_{\mathrm{w}}{ }^{\circ}$, of $\mathrm{HT}$ and its esters were determined in binary stripped olive oil-water mixtures in the absence of emulsifier by employing the shake-flask method. ${ }^{6,9}$ For each $\mathrm{AO}$, a number of binary mixtures were prepared by stirring at high speed for one minute a mixture of $4 \mathrm{~mL}$ of stripped olive oil and $6 \mathrm{~mL}$ of aqueous buffer $(0.04 \mathrm{M}$ citrate buffer. $\mathrm{pH}=$ 3.65). HT and the most polar derivatives, $C_{1}-C_{3}$, were dissolved in the aqueous solution and the more hydrophobic derivatives, $C_{4}-C_{16}$, were dissolved in the olive oil. The final $A O$ concentration in the total $10 \mathrm{~mL}$ emulsion volume was $3.5 \mathrm{mM}$ in all samples. The mixtures were gently shaken for at least 1 minute and allowed to equilibrate at $\mathrm{T}=(25 \pm 1)^{\circ} \mathrm{C}$ for at least 24 hours. The two phases were separated by centrifugation, and the concentrations of the $A O$ in the aqueous and in the oil phases were determined spectrometrically (UV-Vis) at $\lambda=$ $285 \mathrm{~nm}$ by interpolation using previously prepared calibration curves. Each $P_{\mathrm{w}}{ }^{\circ}$ value is an average of duplicate or triplicate measurements. Complete experimental details are published elsewhere ${ }^{8,9}$ The results are summarized in Table 1 in the text.

S.2.3.5. Determining $k_{o b s}$ values for the reaction between $16-\mathrm{ArN}_{2}^{+}$and the AOs in emulsions. 
The reaction between $16-\mathrm{ArN}_{2}{ }^{+}$and the HT and its esters was followed spectrometrically by employing the dye derivatization method (azo dye formation) described in detail elsewhere. ${ }^{4,8,93}$ The methodology exploits the rapid reaction of $16-\mathrm{ArN}_{2}{ }^{+}$ions with a suitable coupling agent such as $\mathrm{N}$-(1-naphthyl)ethylenediamine dihydrochloride, NED, yielding an stable azo dye. Its absorbance was measured spectrometrically at $\lambda=572 \mathrm{~nm}$ after dilution with a 50:50 (v:v) BuOH:EtOH mixture that was an optically transparent, homogeneous solution.

In a typical experiment, a freshly prepared emulsion $(10 \mathrm{~mL})$ containing the required volume of $A O$ stock solution is placed in a continuously stirred, water-jacketed cell ( $T=25 \stackrel{\circ}{\circ})$ and thermostated for at least $15 \mathrm{~min}$. Independently, 25 numbered and stoppered test tubes were placed in a thermostated bath $(\mathrm{T}=25 \stackrel{\circ}{\circ})$ and $2.5 \mathrm{~mL}$ of a $0.02 \mathrm{M} \mathrm{EtOH}-\mathrm{BuOH}(50: 50 \mathrm{v}: \mathrm{v})$ solution of NED were added to each test tube and allowed to reach thermal equilibrium for at least $20 \mathrm{~min}$. After the reaction is initiated, aliquots $(200 \mu \mathrm{L})$ of the reaction mixture were removed at specific time intervals and added immediately to test tubes to quench the reaction by initiating azo dye formation between NED and unreacted $16-\mathrm{ArN}_{2}{ }^{+}$. The absorbance of the azo dye at $\lambda=572 \mathrm{~nm}$ is proportional to the concentration of unreacted $16-\mathrm{ArN}_{2}{ }^{+}$and the decrease in absorbance with time was used to determine the observed first order rate constant, $k_{\text {obs }}$. Values of $k_{\text {obs }}$ were obtained by fitting the absorbance $v s$ time data to the integrated first order rate equation by using a non-linear least squares method provided by the GraFit 5.0.5 computer program.

Figure $\mathbf{S 3}$ shows examples of absorbance versus time plots for azo dye formation and the fitting curves to the integrated and linearized first-order equations for the reactions of 16 $\operatorname{ArN}_{2}{ }^{+}$with the $C_{1}$ and $C_{16}$ derivatives in 4:6 olive oil-in-water emulsions. The excellent fits of the $(A, t)$ data pairs to the first-order kinetic equation demonstrate that any changes in droplet size are not kinetically significant. ${ }^{3-5}$ The results also show that diffusion of reactants is not rate-limiting because if it was, we would not get good first order kinetics. ${ }^{2}$ 

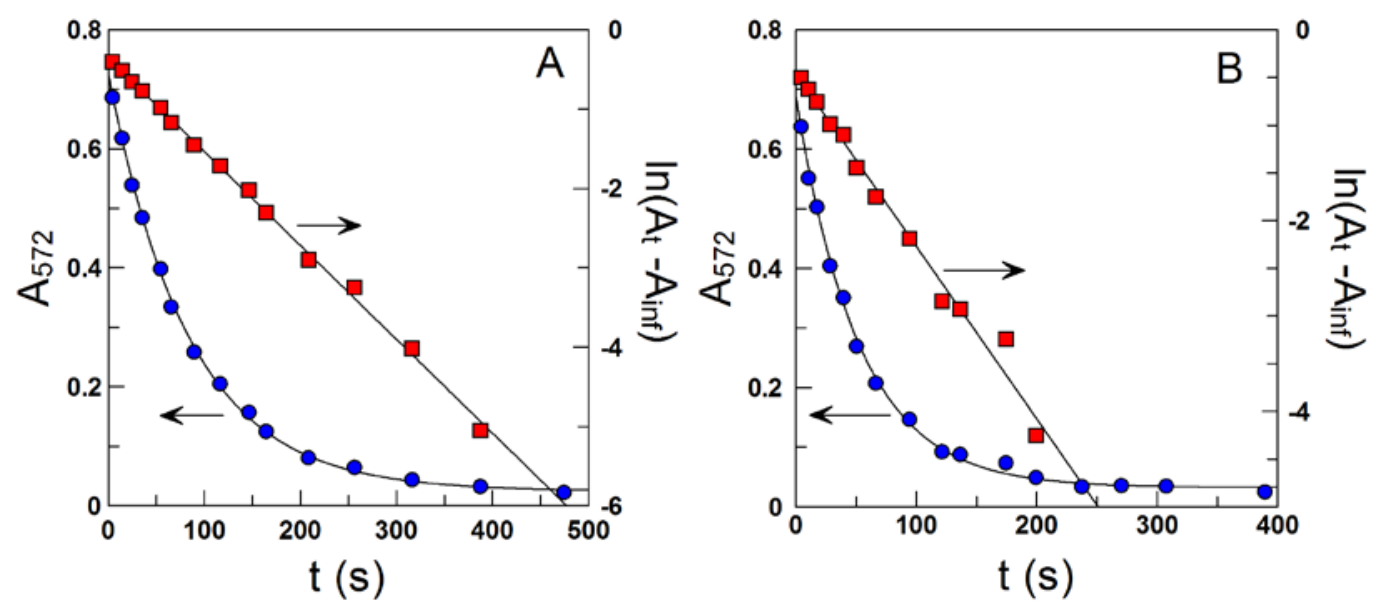

Figure S3. Typical kinetic plots obtained for the reaction of $16-\mathrm{ArN}_{2}{ }^{+}$with the $\mathrm{C}_{1}(\mathrm{~A})$ and $\mathrm{C}_{16}(\mathrm{~B})$ HT derivatives in 4:6 olive oil-in-water emulsions composed of acidic water (citric/citrate buffer, $0.04 \mathrm{M}, \mathrm{pH}=3.65)$ and Tween $20\left(\Phi_{1}=0.0284\right),\left[16-\mathrm{ArN}_{2}{ }^{+}\right] \approx 2.9 \times 10^{-4} \mathrm{M},[\mathrm{AO}]=3 \times 10^{-}$ ${ }^{3} \mathrm{M}, \mathrm{T}=25 \stackrel{\circ}{ } \mathrm{C}$.

\section{S.2.3. Statistical Analysis.}

Duplicate or triplicate kinetic experiments were run for $2-3 t_{1 / 2}$. The $k_{\mathrm{obs}}$ values were within $\pm 7-9 \%$ with typical correlation coefficients of $>0.995$. Reported partition constants in binary oil-water systems are the average of 6 - 8 replicates. The Dixon's Q-test was employed in deciding whether to accept or reject the datum before calculating the average of the set of replicates. All oxidation experiments, Figure 1B in the text, were run in triplicate and SPSS 21.0 software was used for statistical analysis by one-way analysis of variance (ANOVA, with Tukey's HSD multiple comparison) with the level of significance set at $P<0.05$. Data are presented as mean values \pm standard deviation. 
Figure S4. Illustrative variations of the interfacial concentration of representative HT derivatives as a function of the surfactant concentration and the oil to water (o:w) ratio.
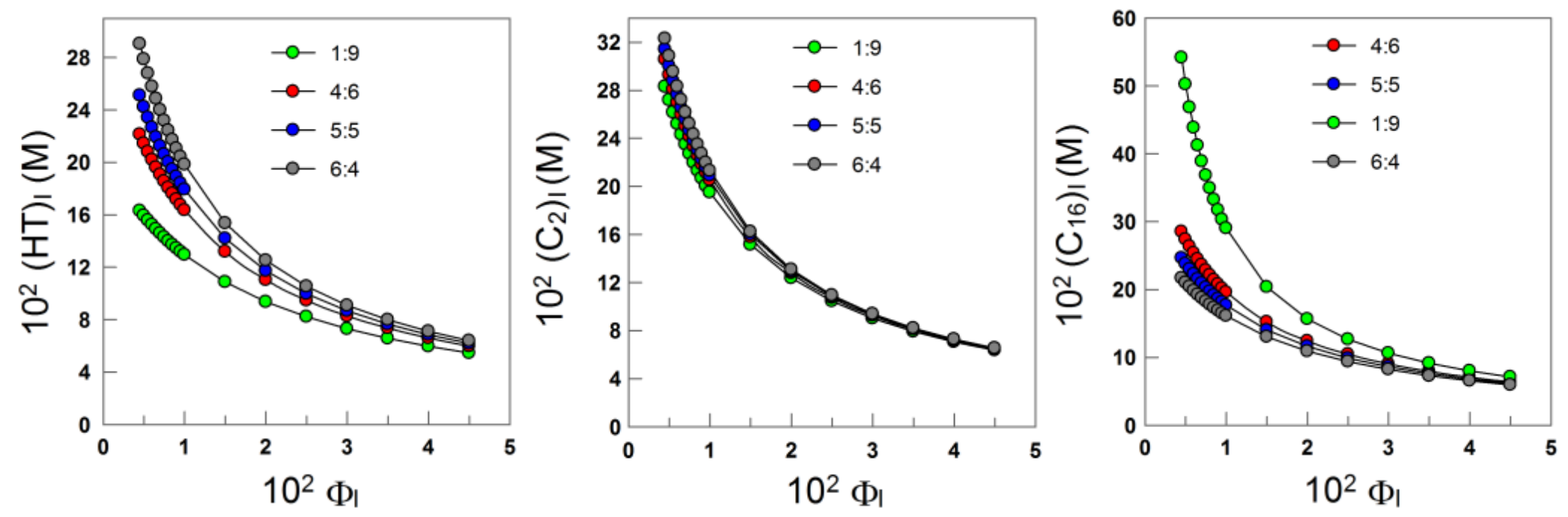
1. Bravo-Díaz, C.; Romsted, L. S.; Liu, C.; Losada-Barreiro, S.; Pastoriza-Gallego, M. J.; Gao, X.; Gu, Q.; Krishnan, G.; Sánchez-Paz, V.; Zhang, Y.; Ahmad-Dar, A., To Model Chemical Reactivity in Heterogeneous Emulsions, Think Homogeneous Microemulsions. Langmuir 2015, 31, 8961-8979.

2. van Boekel, M. A. J. S., Kinetic modeling of reactions in foods. Taylor \& Francis, CRC Press: Boca Raton, FL, 2009.

3. Romsted, L. S.; Bravo-Díaz, C., Modelling chemical reactivity in emulsions. Current Opinion in Colloid and Interface Science 2013, 18, 3-14.

4. Lisete-Torres, P.; Losada-Barreiro, S.; Albuquerque, H.; Sánchez-Paz, V.; Paiva-Martins, F.; Bravo-Díaz, C., Distribution of hydroxytyrosol and hydroxytyrosol acetate in olive oil emulsions and their antioxidant efficiency. J. Agric. Food Chem. 2012, 60, 7318-7325.

5. Losada-Barreiro, S.; Bravo Díaz, C.; Paiva Martins, F.; Romsted, L. S., Maxima in antioxidant distributions and efficiencies with increasing hydrophobicity of gallic acid and its alkyl esters. The pseudophase model interpretation of the "Cut-off effect. J. Agric. Food Chem. 2013, 61, 6533-6543.

6. Losada-Barreiro, S.; Bravo-Díaz, C.; Costa, M.; Paiva-Martins, F., Distribution of catechol in emulsions. J. Phys. Org. Chem. 2014, 27, 290-296.

7. Losada-Barreiro, S.; Costa, M.; Bravo-Díaz, C.; Paiva-Martins, F., Distribution and antioxidant efficiency of Resveratrol in stripped corn oil emulsions. Antioxidants 2014, 3, $212-$ 228.

8. Losada-Barreiro, S.; Sánchez Paz, V.; Bravo Díaz, C.; Paiva Martins, F.; Romsted, L. S., Temperature and emulsifier concentration effects on gallic acid distribution in a model food emulsion. J. Colloid. Interface Sci. 2012, 370, 73-79.

9. Losada-Barreiro, S.; Sánchez Paz, V.; Bravo-Díaz, C., Effects of emulsifier hydrophilelipophile balance and emulsifier concentration the distributions of gallic acid, propyl gallate, and $\alpha$-tocopherol in corn oil emulsions. J. Colloid. Interface Sci. 2013, 389, 1-9.

10. Carda-Broch, S.; García-Alvarez-Coque, M. C.; Simó-Alfonso, E. F.; Esteve-Romero, J. S., Anal. Chim. Acta 1997, 353, 215 and references therein.

11. Torres de Pinedo, A.; Peñalver, P.; Rondón, D.; Morales, J. C., Efficient lipase-catalyzed synthesis of new antioxidants based on a catechol structure. Tetrahedron 2005, 61, 7654-7660. 12. Fernández-Bolaños, J. G.; López, O.; Fernández-Bolaños, J.; Rodríguez-Gutiérrez, G., Hydroxytyrosol and Derivatives: Isolation, Synthesis, and Biological Properties. Current Organic Chemistry 2008, 12, 442-463. 
13. Costa, M.; Losada-Barreiro, S.; Paiva-Martins, F.; Bravo-Díaz, C.; Romsted, L. S., A direct correlation between the antioxidant efficiencies of caffeic acid and its alkyl esters and their concentrations in the interfacial region of olive oil emulsions. The pseudophase model interpretation of the "cut-off" effect. Food Chem. 2015, 175, 233-242.

14. Frankel, E. N., Lipid Oxidation. The Oily Press, PJ Barnes \& Associates: Bridgwater, England, 2005.

15. AOCS, Official Methods and Recommended Practices of the AOCS. AOCS: Urbana, IL, USA, 2013. 